\title{
HIGH-TEMPERATURE HEAT PUMP SIMULATOR (HEATPACK) FOR APPLICATION IN COMPUTER LABORATORY SESSIONS FOR ENGINEERING STUDENTS
}

\author{
Adrián Mota-Babiloni (iD), Carlos Mateu-Royo (D), Joaquín Navarro-EsbríiD, \\ Ángel Barragán-Cervera \\ Universitat Jaume I (Spain) \\ mota@uji.es,mateu@uji.es,navarroj@uji.es,abarraga@uji.es
}

Received February 2020

Accepted July 2020

\section{Abstract}

A significant amount of energy in the form of heat is lost in industrial processes once it is used in specific processes. Among different technologies, high-temperature heat pumps (HTHP) are a valuable method of recovering low-temperature waste heat in the industry in a very efficient way that can be activated using clean electricity. As a recently investigated technology, they are not yet spread in industrial processes, where traditional technologies are preferred. Therefore, this work shows an HTHP computer program (named HeatPack) to be used as a simulator by the university or technical students of courses included in applied thermodynamics engineering. This interactive and user-friendly platform allows the modification of different operating and design parameters and the working fluid. As outputs, the program provides the rest of the operating parameters and the energy performance of the cycle (quantified by the coefficient of performance, COP). The proposed HTHP and a gas boiler are compared by the program and the energetic, carbon footprint, and economic savings are displayed. Students, as the main target of users of the program, can observe how this technology can provide benefits. For instance, emission reductions in comparison with fossil fuel-based boilers, under which situation the energy performance of the HTHP is higher, and which alternative low global warming potential (GWP) refrigerants can provide more advantages. In addition to the educational use, this software can be used to design and study the integration of HTHPs in existing industrial needs to evaluate the feasibility.

Keywords - High-temperature heat pump (HTHP), Computer program, Applied thermodynamics, Decarbonization, Waste heat recovery (WHR), Industry.

\section{To cite this article:}

Mota-Babiloni, A., Mateu-Royo, C., Navarro-Esbrí, J., \& Barragán-Cervera, Á. (2021).

High-temperature heat pump simulator (HeatPack) for application in computer laboratory sessions for engineering students. Journal of Technology and Science Education, 11(1), 16-29. https://doi.org/10.3926/jotse. 952

\section{Introduction}

Climate change is considered today a significant threat because of its catastrophic consequences. The Paris Agreement aims to strengthen the global response to the climate change by limiting the global 
mean surface temperature rise by 2100 well below $2{ }^{\circ} \mathrm{C}$ above pre-industrial levels (Rogelj, Den Elzen, Höhne, Fransen, Fekete, Winkler et al., 2016). Trained professionals with environmental awareness are needed to reduce the magnitude of this phenomenon and reduce the consequences, in the development of sustainable technologies as well as in the promotion of the necessary cultural changes (Kaikai \& Baker, 2016). Ambusaidi, Boyes, Stanisstreet, and Taylor (2012) showed that environmental and social awareness of students are connected to the concepts worked during the courses. Therefore, dealing with energy efficiency concepts in the classroom can be useful. European Universities Association (EUA) published that these instructions play a critical role as crucial energy stakeholders (European University Association, 2017). Cawsey (1996) described different examples of innovative education and training systems, associations, and networks with regional, national and international objectives to make pro-active professionals of engineering in defense of the environment and to be able to influence in the future.

The subjects related to thermodynamics can be an excellent way to transmit this knowledge by the relationship of energy consumption and use with climate change. However, according to Ugursal and Cruickshank (2015), this group of assignments are those that require the most effort and time from other students. They also conclude that, if students begin to find interesting and exciting material, they will probably spend even more time working on the concepts and learning it better. A survey performed by Michna and Gent (2011) in Mechanical Engineering students evidenced difficulties when linking the ideas of laboratory sessions to the lecture courses in thermodynamics, fluid mechanics and heat transfer. Students felt that these courses did not significantly contribute to their learning in the mechanical engineering program. Experiments in a physical lab impose a valuable, hands-on experience for the students, while a simulation-based lab provides an active experiment environment that is comfortable for the students (Balakrishnan \& Woods, 2013). Therefore, Balakrishnan and Woods (2013) concluded that physical and simulation labs support and complement each other.

Chaturvedi and Akan (2006) concluded that simulation and visualization have great potential to enhance student learning and the quality of engineering education. Taraban, Anderson, DeFinis, Brown, Weigold and Sharma (2007) confirmed that students expressed significantly more cognitive activity on computer screens requiring interaction compared to text-based screens. In this way, computer laboratory sessions are used regularly to assimilate the concepts seen in theory and problems sessions differently and interactively. Although these methodological concepts can be applied in various areas of engineering, computer applications developed by university teaching teams in the field of thermodynamics can be very useful. Martin, Moore and Ranalli (2016) stated that educational software promotes higher-level cognitive thinking in problem-solving, allowing them to focus on more holistic questions of cycle performance. The resolution of problems and cases with complicated thermodynamic cycles is often prohibitive by hand, and result very useful in the analysis of trends or to check the steps of calculations (Tebbe, Weisbrook, Lombardo \& Miller, 2001). Antón, Jonsson, Ramos and Gómez-Acebo (2009) concluded that vapor compression cycle simulators provide additional time for teachers to analyze cycle performance with students and enrich the quality of teaching in both directions. However, they warn that this type of simulators is not enough and should be complemented with appropriate guides.

Zueco (2013) highlighted that Engineering Equation Solver (EES) is a tool that offers the possibility of creating thermodynamic models to solve quickly and accurately different types of problems in which the most important tasks are those related to engineering. Gaggioli (2010) has reached a similar conclusion but using EES as reference software. They as concluded that is exceptionally beneficial in thermodynamic courses because it helps the student in focusing upon the fundamentals and determining the proper balances instead of the time-intensive task of looking in classical tables and charts. Cabello, Llopis, Sánchez and Torrella (2011) developed REFLAB, a tool that allows evaluating different operational and energy parameters online in a vapor compression system, which was satisfactorily accepted by the students. Belman-Flores, Barroso-Maldonado, Mendez-Díaz and Martínez-Martínez (2015) used EES to represent the behavior of a vapor compression system. They designed a robust program due to the broad operating range that simulates. 
Due to the recent interest in electrical driven heat pumps in the industry to replace fossil fuel burners (Wallerand, Kermani, Kantor \& Maréchal, 2018), it becomes necessary a program developed in a commonly used software (in this case, EES) to approach the technology to engineering students. The main objective of this work is to create a program that can be used by students of different Bachelor's and Master's Engineering Degrees with a base of knowledge thermodynamics. This program is used to practice and understand the benefits of heat pumps used for industrial waste heat recovery, also known as High-Temperature Heat Pump (HTHP). The program must offer the user different possibilities in terms of design to understand the consequences of the operation under different conditions and the selection of various working fluids (also known as refrigerants). Other essential requisites for the software is being visual, to catch student's attention and the most accurate representation of reality. Obtained results will allow students to apply and discuss thermodynamics concepts, reinforcing the link between this science and industrial processes.

\section{Program Development}

Engineering Equation Solver (EES) is a general equation-solving program that can numerically solve thousands of coupled nonlinear algebraic and differential equations. A remarkable feature of EES is the comprehensive database of high-precision transport and thermodynamic properties for hundreds of substances (Klein, 2006). EES is an intuitive software and in some applied thermodynamic courses is commonly used to simulate the operation of Rankine cycles for electricity generation from vapor, and inverse Rankine cycles as refrigeration a regular heat pump working at different configurations, refrigerants, and levels of complexity.

EES is selected because of its massive user base, like the rest of the software engineering used in other courses (Hannay, MacLeod, Singer, Langtangen, Pfahl \& Wilson, 2009). EES is linked to REFPROP software (Lemmon, Bell, Huber \& McLinden, 2018) and uses the information contained in its files to load and simulate the working fluids. The flexibility of the EES software allows to introduce modifications and include new components or recently developed environmentally friendly (low global warming potential, low-GWP) working fluids to develop a program with a greater number of options. REFPROP is a computer program that provides thermophysical properties of pure fluids and mixtures over a wide range of fluid conditions.

Heaton and Carver (2015) claimed that software developers do not know how to reflect many of the real experimental practices in computer programs. Before developing this tool, researchers involved in this work have built an HTHP prototype, and have tested it at different operating conditions analyzing its energetic, exergetic and environmental results (Mateu-Royo, Navarro-Esbrí, Mota-Babiloni, Molés \& Amat-Albuixech, 2019). Moreover, information already contained in recently published reviews like those of (Arpagaus, Bless, Schiffmann \& Bertsch, 2016; Bamigbetan, Eikevik, Nekså \& Bantle, 2017) can be used in program development preliminary tasks. The following aspects has been considered to obtain the most approximate to reality and useful simulator:

- Most used Configurations for HTHPs, for instance, single stage, single stage with IHX, two stage cascade, vapor/liquid injection, etc.

- Working fluids attending to their thermophysical, safety, and environmental characteristics in typical HTHPs operating range, for instance, HFC-245fa, R-600, R-601, HFO-1336mzz(Z), HCFO-1224yd, R-514A, etc.

- Volumetric, isentropic and overall efficiency of the compressor: developed by previous works, constant values, regressions made using commercial compressor catalogues, etc.

- Stablishing common assumptions in vapor compression systems. Among them, neglecting heat transfer to the surroundings and pressure drops in components and pipelines, and isenthalpic process in the expansion device (Mateu-Royo, Navarro-Esbrí, Mota-Babiloni, Amat-Albuixech \& Molés, 2018). 
- Limiting the number of equations included while keeping the interest of the results provided. Although the use of EES requires a license, there is a limited free version for educational purposes.

After considering the aforementeioned factors, resulting simulator has been developed as follows:

1. The configuration simulated is a single stage HTHP (Figure 1). Because of its simplicity can be used by several students from different degrees (electrical, chemical engineering, industrial, etc.) with a basic knowledge in thermodynamics. Calculations can be validated manually by the students.
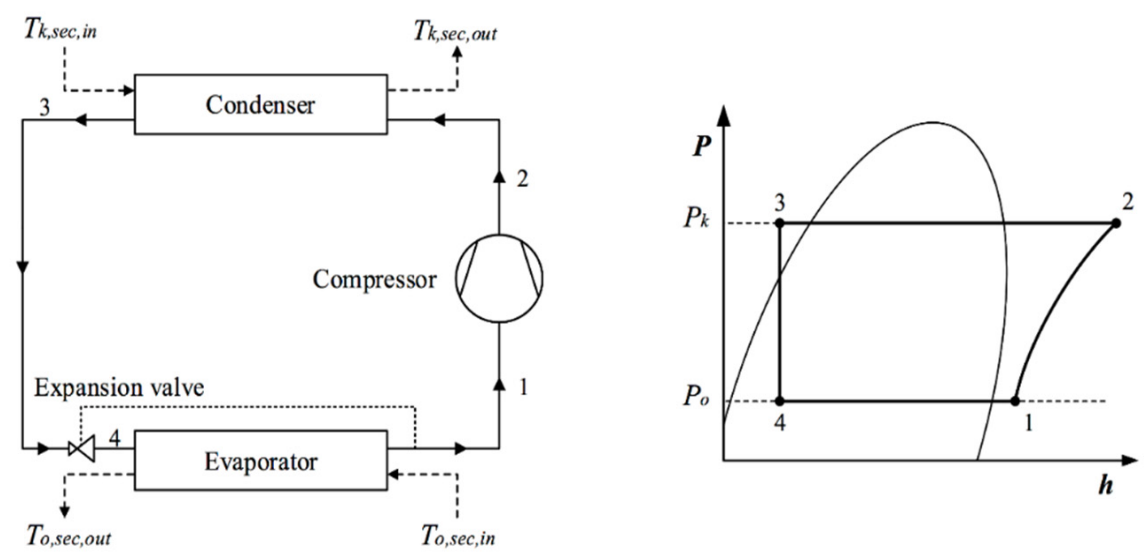

Figure 1. Vapour compression HTHP and Ph Diagram.

2. The refrigerants selected are HFC-245fa, HFO-1336mzz(Z), HCFO-1233zd(E), R-600 (butane), and R-601 (pentane). They have been considered because their commercial availability, low GWP, zero or neglibible ODP, and suitable operating conditions (Figure 2).
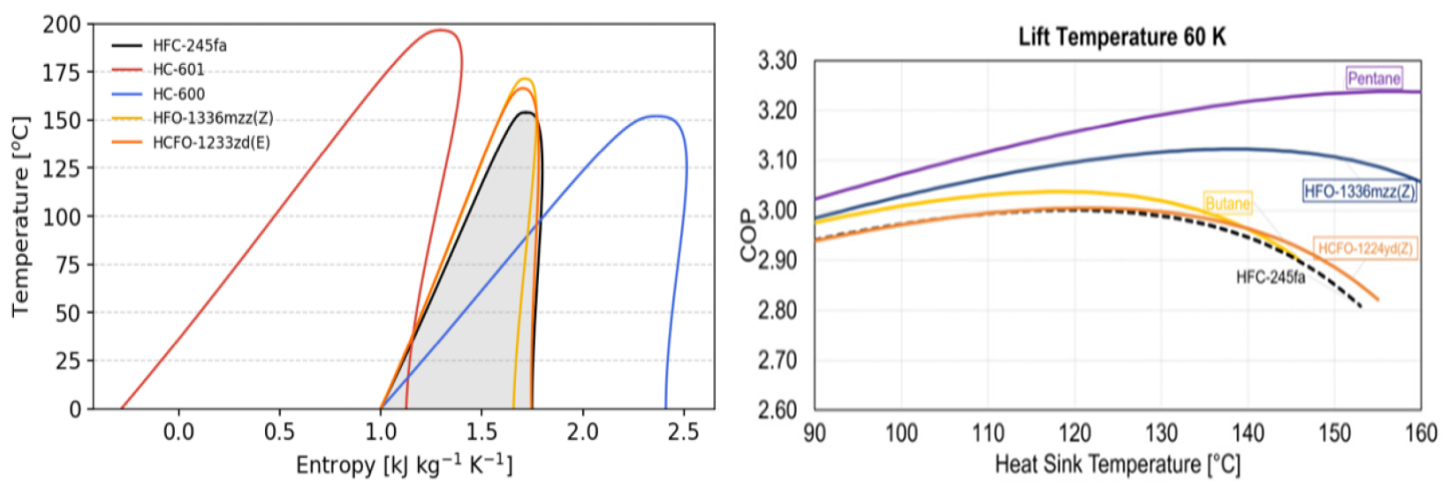

Figure 2. Ts diagram and COP at different heat sink temperatures for the selected refrigerants.

3. Equations that define the thermodynamic states of the refrigerant, as well as the operating parameters and compressor efficiencies (Table 1).

4. Development of the graphical interface for the use of the software that can provide the maximum of outputs, and it is clear to understand and worked by the users. They can modify, typically SHD and SCD can be proposed in the design stage of the HTHP, hothers are going to be proposed by the situation of the project; and

5. definition of the parameters to compare the HTHP with a conventional fossil fuel boiler (Table 2). 


\begin{tabular}{|c|c|}
\hline Part of the circuit & Equations used \\
\hline Compressor & $\begin{array}{c}\dot{W}_{\mathrm{C}}=\frac{\dot{m} \Delta h_{i s, c}}{\eta_{i s} \eta_{e m}} \\
h_{\text {disc }}=\frac{h_{\text {disc } i s o}-h_{s u c}}{\eta_{i s}}+h_{s u c} \\
\eta_{e m}=0.95 \\
\text { Based on Pierre's correlations for "good" reciprocating compressors } \\
\text { (Granryd, Ekroth, Lundqvist, Melinder, Palm \& Rohlin, 1999): } \\
\eta_{v o l}=k_{1} \cdot\left(1+k_{s} \cdot \frac{t_{2 k}-18}{100}\right) \cdot \exp \left(k_{2} \cdot \frac{p_{1}}{p_{2}}\right) \\
\left(\frac{\eta_{v o l}}{\eta_{i s}}\right)=\left(1+k_{e} \cdot \frac{t_{2 k}-18}{100}\right) \cdot \exp \left(a \cdot \frac{T_{1}}{T_{2}}+b\right)\end{array}$ \\
\hline Condenser & $\begin{array}{c}T_{k, \text { out }}=T_{k}-S C D \\
\dot{Q}_{\mathrm{k}}=\dot{m}\left(h_{k, \text { in }}-h_{k, \text { out }}\right)\end{array}$ \\
\hline Expansion valve & $h_{x v, o u t}=h_{x v, \text { in }}$ \\
\hline Evaporator & $\begin{array}{c}T_{o, \text { out }}=T_{o}+S H D \\
\dot{m}=\frac{\dot{Q}_{o}}{\left(h_{o, \text { out }}-h_{o, \text { in }}\right)}\end{array}$ \\
\hline Overall & $C O P=\frac{\dot{Q}_{k}}{\dot{W}_{C}}$ \\
\hline
\end{tabular}

Table 1. Equations used for modelling the HTHP operation

\begin{tabular}{|c|c|c|c|}
\hline Analysis & Equation & Parameters boiler & Parameters HTHP \\
\hline Energetic & $E=\dot{W} \cdot h$ & $\begin{array}{c}\text { Set by students, but } 95 \% \text { by } \\
\text { default }\end{array}$ & From Table 1 \\
\hline Economic & $C=\dot{E} \cdot h \cdot$ cost & $\begin{array}{c}\text { cost }=0.05 € \mathrm{kWh}^{-1} \\
\text { (based on real invoices) }\end{array}$ & $\begin{array}{c}\text { cost }=0.13 € \mathrm{kWh}^{-1} \\
\text { (based on real invoices) }\end{array}$ \\
\hline Carbon footprint & Emissions $=\dot{E} \cdot h \cdot \beta$ & $\begin{array}{c}\beta=252 \mathrm{~g} \mathrm{CO}_{2} \mathrm{kWh}^{-1} \text { (natural } \\
\text { gas, final energy value) }\end{array}$ & $\begin{array}{c}\beta=399 \mathrm{~g} \mathrm{CO}_{2} \mathrm{kWh}^{-1} \\
\text { (Spain, final energy value) }\end{array}$ \\
\hline
\end{tabular}

Table 2. Equations used for the multi-purpose comparison of the HTHP and a conventional gas boiler

\section{Software Visual Interface}

The HTHP interface has been designed to be clear, visual, and straightforward while containing all the inputs/outputs. After focusing on, the interface is intended attending to programmatic as well as pedagogical thoughts to be developed for a different number of courses, as recommended by Tebbe et al. (2001). The resulting EES HTHP interface is shown in Figure 3. The students can follow the operating conditions on the schematic representation of the HTHP and modify the input conditions of and the working fluid to be used. Afterwards, they can check the energetic parameters and an additional energetic, economic, and carbon footprint comparison with a conventional gas boiler.

In the top of the screen, the users can select the desired working fluid including the traditional HFC-245fa option, and new synthetic and natural alternatives as HFO-1336mzz(Z), HCFO-1233zd(E), butane (R-600) and pentane (R-601). As the primary purpose of the utilization of HTHP in industrial processes is to reduce the carbon footprint, the GWP of the proposed working fluids is shown to facilitate the decision of the user. Then, default values for the superheating and the subcooling degrees (SHD and SCD) usually seen in HTHPs are proposed, but the user can modify the selection and test different options. 


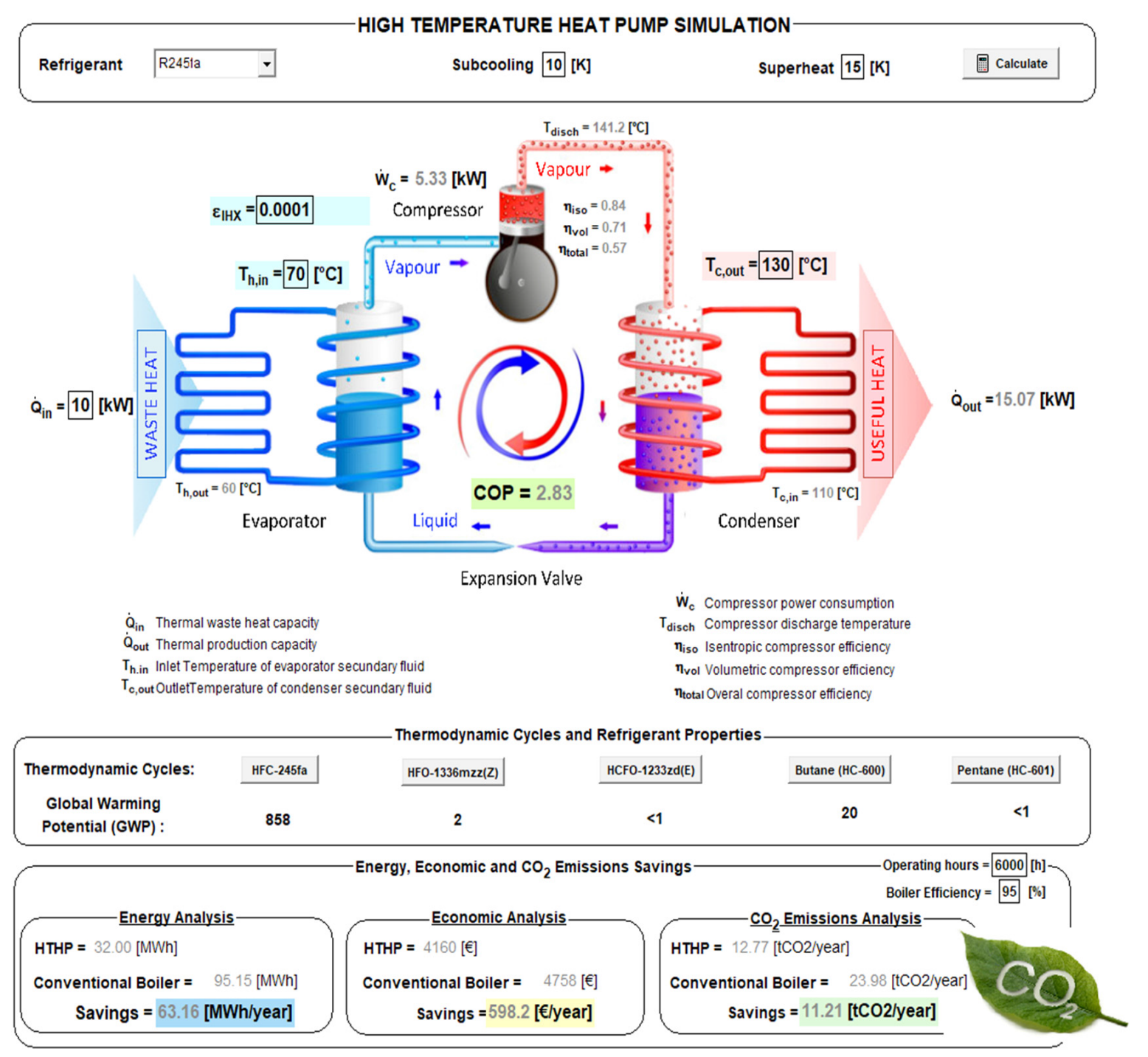

Figure 3. HeatPack main screen and interface

The next element shown in the screen is the schematic of the HTHP, where the main elements of the system (compressor, condenser, expansion valve, and evaporator) can be easily identified. For beginner users, the circulation of the working fluid the energy flow is represented. The different thermodynamic states of the refrigerant are also graphically differenced in colors and by specifying it with labels. The nomenclature of the main parameters shown in the schematic is described below. As inputs, the user can introduce the recovered waste heat $\left(\mathrm{Q}_{\text {in }}\right)$, the heat sink and heat source temperatures $\left(\mathrm{T}_{\mathrm{h} \text {,in }}\right.$ and $\left.\mathrm{T}_{\mathrm{c}, \mathrm{out}}\right)$. As outputs, the user can observe the heat sink inlet and heat source outlet temperatures $\left(T_{c, \text { in }}\right.$ and $\left.T_{h, o u t}\right)$, the discharge temperature $\left(\mathrm{T}_{\text {disc }}\right)$, the compressor efficiencies $\left(\eta_{\text {iso }}, \eta_{\text {vol }}\right.$ and $\left.\eta_{\text {total }}\right)$, the high-temperature heat power delivered ( $\mathrm{Q}_{\text {out }}$ ) and the coefficient of performance (COP), being the last one highlighted in the center of the schematic as it can be considered the main energetic parameter. Finally, to carry out the simulation and see the results, the calculations can be started by pressing the button 'calculate'.

The carbon footprint analysis $\left(\mathrm{tCO}_{2}\right.$ per year) is considered of great interest for the students. They can be able to see the significant reduction of $\mathrm{CO}_{2}$ by the introduction of this electrically driven technology in comparison with natural fuel-powered boilers. This is confirmed in a previous Life Cycle Analysis through the eco-indicator level (Nitkiewicz \& Sekret, 2014). Additionally, different refrigerants or operating conditions will result in different COPs, and this is going to cause a variation in the benefits in terms of environment protection. 
Moreover, the dynamic thermodynamic cycle followed by the HTHP can be displayed in a Pressure-specific enthalpy (P-h) diagram. It includes the saturation lines and some isothermal and isentropic lines. It is modified each time the parameters or refrigerants are modified and helps the students to reinforce the concepts of the operation of vapor compression cycles and understand the reason for the variation of the COP (Figure 4). The figure analysis can be used for an open discussion with students or tasks at the end of the computer session.

Finally, this simulation tool has been designed to be used individually. Still, engineering students can use it to work in groups in collaborative projects in the topic of energy saving in industry. The utilization of engineering software in collaborative projects can end in better understanding of the thermodynamics concepts and better performance on the final exam (Wright, 2018).

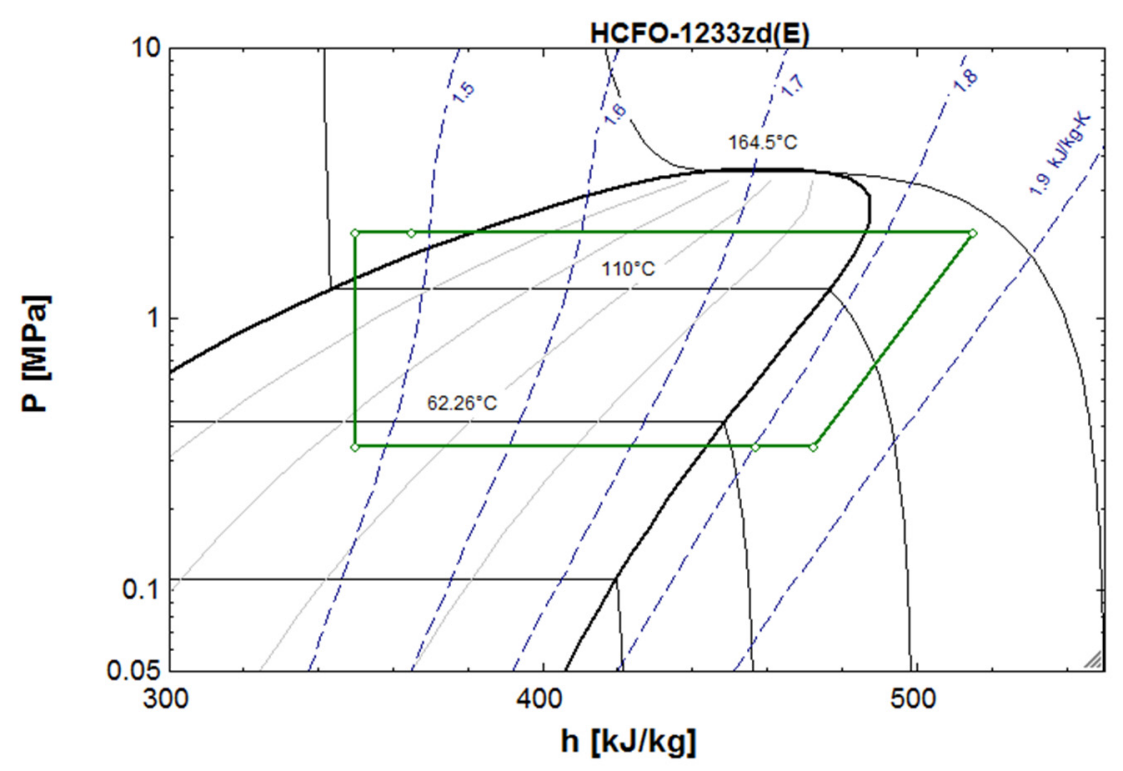

Figure 4. P-h diagram, saturation lines, and HTHP operation with HCFO-1233zd(E) generated by HeatPack.

\section{Examples of Program Application}

This utilization of HeatPack is proposed in a computer laboratory session attending to the high potential of HTHP systems in industrial processes of different sectors. This tool is useful to show to the engineering students' other possibilities of applications for the vapor compression systems, beyond refrigeration, air conditioning and residential heat pumps, helping them to assimilate the concepts taught in theory sessions. During the development of the computer laboratory session, the laboratory assistant can propose to the students to simulate the HTHP operation using different refrigerants. Given the variety of refrigerants available in the program, the refrigerant used by each student or group can be altered so they will arrive at different solutions and a discussion comparing the results found by each working unit can be discussed and analyzed together. The same proposal can be applied to the operating conditions, studying the savings offered by each case. Finally, students can sum up the conclusions of the work and the main ideas exposed in the session in a final report that can be worked on the session or at home, depending on the distribution of the laboratory session/home hours.

Different types of analysis can be proposed to study the different options of use of the HTHP. In this section, a possibility for the variation of several parameters (sensitivity analysis) in the energy performance of the HTHP, and the energy, economic and carbon footprint parameters is proposed. Various cases are offered varying one parameter to see its effect on the different types of analysis (Table 3), and the main results are shown in Figure 5. 


\begin{tabular}{|c|c|c|c|c|c|c|c|c|}
\hline Case & Action & Refrigerant & $\begin{array}{c}\text { SCD } \\
{[\mathbf{K}]}\end{array}$ & $\begin{array}{c}\text { SHD } \\
{[\mathbf{K}]}\end{array}$ & $\begin{array}{c}\boldsymbol{Q}_{\text {in }} \\
{[\mathbf{k W} \boldsymbol{W}]}\end{array}$ & $\begin{array}{c}\boldsymbol{T}_{\boldsymbol{h} \text {,in }} \\
{\left[{ }^{\circ} \boldsymbol{C}\right]}\end{array}$ & $\begin{array}{c}\boldsymbol{T}_{\text {c,out }} \\
{\left[{ }^{\circ} \boldsymbol{C}\right]}\end{array}$ & $\begin{array}{c}\text { Working } \\
\text { hours }\end{array}$ \\
\hline 1 & Base & R-245fa & 10 & 15 & 10 & 70 & 130 & 4000 \\
\hline 2 & New refrigerant & HCFO-1233zd(E) & 10 & 15 & 10 & 70 & 130 & 4000 \\
\hline 3 & Subcooling degree (SCD) x2 & R-245fa & 20 & 15 & 10 & 70 & 130 & 4000 \\
\hline 4 & Superheating degree (SHD) x2 & R-245fa & 10 & 30 & 10 & 70 & 130 & 4000 \\
\hline 5 & Waste heat rate x2 & R-245fa & 10 & 15 & 20 & 70 & 130 & 4000 \\
\hline 6 & Heat sink temperature +20K & R-245fa & 10 & 15 & 10 & 90 & 130 & 4000 \\
\hline 7 & Heat source temperature +15K & R-245fa & 10 & 15 & 10 & 70 & 145 & 4000 \\
\hline 8 & Working hours x1.5 & R-245fa & 10 & 15 & 10 & 70 & 130 & 6000 \\
\hline
\end{tabular}

Table 3. Proposed conditions for the simulation and practice with the HeatPack software
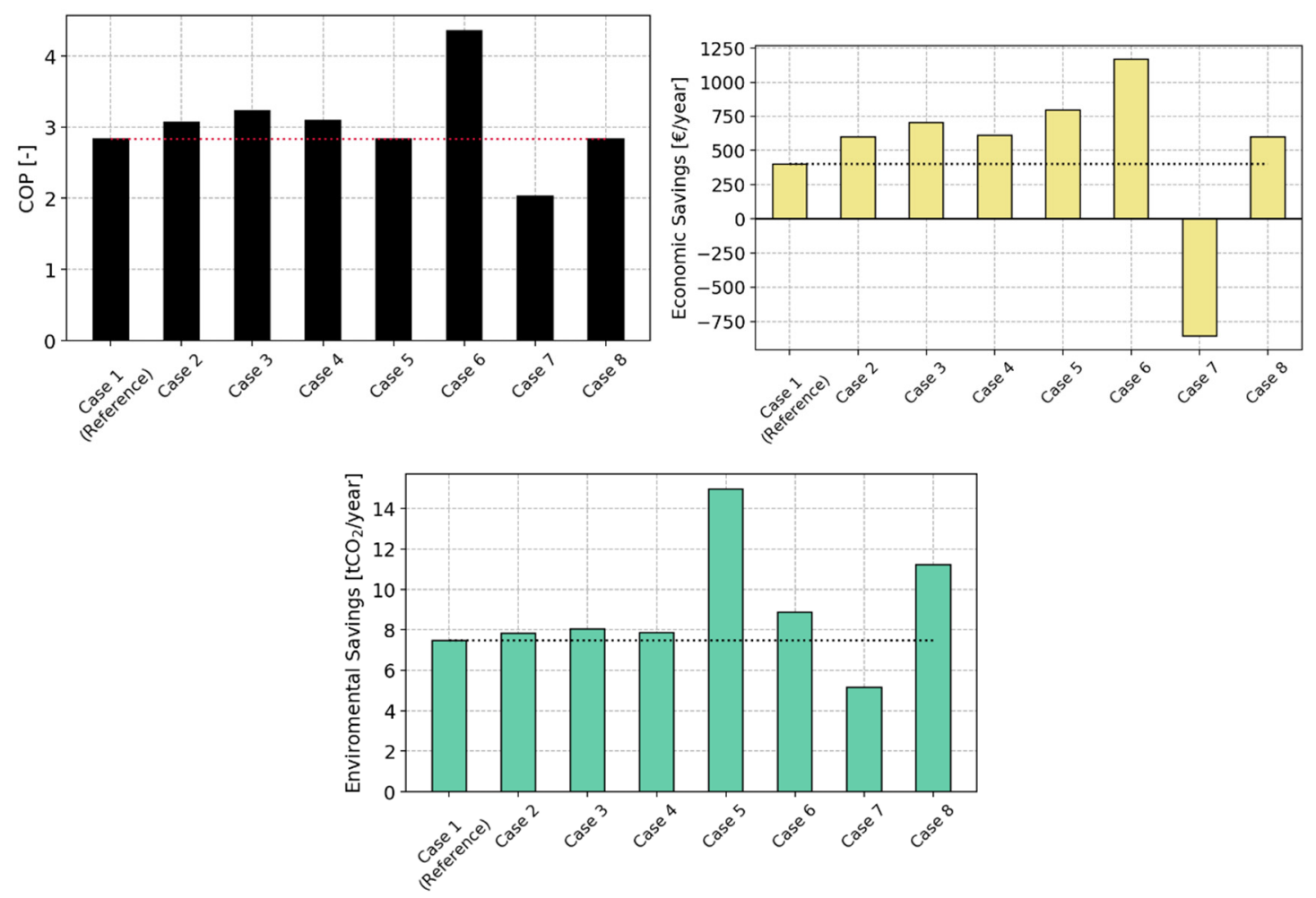

Figure 5. Results obtained by the students to study the influence of the input parameters in an HTHP

All proposed cases reflect possible scenarios observable in HTHPs in operation and decisions related to these parameters are usual in HTHPs design. First, the most common refrigerant and operating conditions have been proposed. Then, a different low GWP working fluid is introduced because future engineers will face refrigerant selection and replacement situations. In the following, different key operating parameters are intended to be modified in a magnitude able to reflect the visually and numerically observe the effects of integrating HTHPs with varying types of heat sink and sources. Moreover, future engineers will have to set superheating and subcooling degrees in HTHPs or identify unnormal operation caused by the variation of these parameters. Finally, it is interesting that students learn how the change of working hours influences the economic viability of HTHP projects. It must be mentioned that the variation of the parameters is significant but remains within the limits of regular operation.

Figure 5 is shown as an example of what Engineering students should deliver in the computer laboratory report at the end of the session within a few days. In the analysis of the discussion of these results, they can observe how using refrigerants such as HFO-1336mzz(Z), HCFO-1233zd(E) (case 2), butane and npentane can end in economic and emissions savings. The difference between the heat source and heat sink temperature (cases 6 and 7) and the energy required by the system are increased, whereas the energy 
performance decreases. Variation of SCD and SHD parameters (cases 3 and 4, respectively) have a lower influence on the analyzed parameters. Still, they are very relevant for the HTHP design and operation. Finally, the higher the heat load and the operating hours (cases 5 and 8), the higher the benefit in the energetic, economic, and carbon footprint aspects analyzed.

\section{The Potential Application of the HeatPack Software}

After developing this version of HeatPack, a screening of the main courses to introduce its use has been used taking as reference the School of Technology and Experimental Sciences of the University (ESTCE) Jaume I of Castelló (Spain). This university is public and was established in 1991 and teaches to approximately 15000 students (Universitat Jaume I, 2019). A screening of the ESTCE studies is performed to verify which courses could be used this program in computer laboratory sessions. The course syllabus of each course has been analyzed and the selected courses, of different Bachelor's Degrees (BD), specifying the year, and University Master's Degrees (UMD), and the results are summarised in Table 4.

Considering the number of new access places offered the course 2019/20 and degree, a total of 395 students can be benefited from the utilization of the program developed and their thermodynamic knowledge could be strengthened. Under certain conditions and on specific occasions, a computer laboratory session may indeed qualify as a valid substitute of experimental laboratory session (Balakrishnan \& Woods, 2013).

\begin{tabular}{|c|c|}
\hline Degree & Course \\
\hline $\mathrm{BD}$ in Chemical Engineering & $\begin{array}{l}\text { Applied Thermodynamics }\left(2^{\text {nd }} \text { year }\right) \\
\text { Industrial Chemical Processes }\left(3^{\text {rd }} \text { year }\right) \\
\left.\text { Water and Energy Technology in the Chemical Industry ( } 4^{\text {th }} \text { year }\right) \\
\text { Process Simulation and Optimization }\left(4^{\text {th }} \text { year }\right)\end{array}$ \\
\hline BD in Electrical Engineering & $\begin{array}{l}\text { Renewable Energy Installations }\left(3^{\text {td }} \text { year) }\right. \\
\text { Energy Management in Industrial Plants }\left(4^{\text {th }} \text { year }\right) \\
\text { Supplement to Renewable Energies }\left(4^{\text {th }} \text { year }\right) \\
\left.\text { New Energy Technologies ( } 4^{\text {th }} \text { year }\right)\end{array}$ \\
\hline $\mathrm{BD}$ in Mechanical Engineering & $\begin{array}{l}\left.\text { Air Conditioning and Refrigeration Systems ( } 4^{\text {th }} \text { year }\right) \\
\text { Heating Machines and Systems }\left(3^{\text {rd }} \text { year }\right)\end{array}$ \\
\hline BD in Industrial Technology Engineering & Industrial Heating and Cooling $\left(4^{\text {th }}\right.$ year $)$ \\
\hline UMD in Energy Efficiency and Sustainability & $\begin{array}{l}\text { Waste Recovery and Valuation } \\
\text { Energy Recovery in the Industry Options and Technologies } \\
\text { Energy Efficiency Improvement }\end{array}$ \\
\hline UMD in Industrial Engineering & Energy Design of Thermal Machines and Installations \\
\hline
\end{tabular}

Table 4. Courses in which HeatPack can be used

\section{Future Improvements to the Program 6.1. Advanced Configurations}

This software only has included the basic cycle configuration which has been used by most of the HTHP prototypes today developed (Arpagaus, Bless, Uhlmann, Büchel, Frei, Schiffmann, 2018; Bamigbetan, Eikevik, Nekså, Bantle \& Schlemminger,, 2019). The simplicity in the design, control and maintenance, and the lower initial costs justify this decision. However, advanced configurations as two-stage cycles or two-stage cascade (with or without internal heat exchanger) can improve the energy performance observed in basic cycle HTHP (Mateu-Royo et al., 2018; Mota-Babiloni, Mateu-Royo, Navarro-Esbrí, Molés, Amat-Albuixech \& Barragán-Cervera, 2018). With the development and the spread of the technology advanced and more complex configurations are expected to come. 


\subsection{Additional Working Fluids}

In this version of the HeatPack software, we proposed five working fluids: the typically used working fluid (HFC-245fa), two synthetic refrigerants (HFO-1336mzz(Z) and HCFO-1233zd(E)) and two natural fluids (butane and pentane). However, more pure working fluids have been recently proposed (Frate, Ferrari \& Desideri, 2019), even though they perform worse than the refrigerants included in this software. However, the user should be able to check by himself/herself the potential of each refrigerant. Additionally, fluid mixtures with zeotropic behavior have shown a potential to increase the energy performance of HTHPs (Zühlsdorf; Jensen \& Elmegaard, 2019). The possibility of blending refrigerants as well as advanced heat exchanger simulation could represent an exciting improvement for future versions of the software.

\subsection{Reversible HTHP/ORC System}

Besides HTHPs, Organic Rankine cycles (ORC) are a method that can be used to recover low-temperature waste heat. Most of the ORC expanders are built using a modified compressor to operate in the opposite direction and extract the energy from the working fluid and convert it into mechanical (and then, electrical through a generator) (Mahmoudi, Fazli \& Morad, 2018). Dickes, Dumont, Legros, Quoilin and Lemort (2015) proposed a reversible HT/ORC cycle that can operate in building applications under both modes providing heat, cold or electricity, depending on the needs of the installation. Peris-Pérez, Navarro-Esbrí, Molés, Mota-Babiloni, Amat-Albuixech, Mateu-Royo et al. (2018) extended this analysis to HTHP to propose this option in industrial environments. As the simulation of the technology was developed using EES, it could be simplified and introduced in the code of HeatPack to have higher economic savings in comparison with the fossil fuel boiler.

\section{First Educational Experiences}

This software was used for the first time in the course "Supplement to Renewable Energies", in the $4^{\text {th }}$ year of the BD in Electrical Engineering (15 students). The computer laboratory session took place a few days after learning the basics of heat pumps. The organization was as follows: 1) Introduction to remember the basics of heat pumps and its potential applications, 2) Explanation of the software and its potentialities, 3) Variation of parameters, and observations about the results, 4) Draft of the laboratory session report (that they have to complete and send to the lecturer up to a week later). In the following, the different discussions appeared about the software, application, and conclusions of the session are presented.

First, the lecturer was inquired about the difference between conventional heat pumps and high-temperature heat pumps. Therefore, the lecturer explained the relevance of removing fossil fuel boilers at any temperature level and the relevance of revalorizing waste heat. HTHPs can cover a higher range of applications with greater heating capacity than conventional heat pumps, and the carbon footprint benefit is improved.

The lecturer also discussed with the students the deviations between software calculations and the real performance of HTHPs. The students were surprised because, according to the lecturer, the differences are not significant because of the compressor correlations. However, before using the software in the session, the results of the correlations was checked and the way this correlation was obtained was shown (Navarro-Peris, Corberán, Falco \& Martínez-Galván, 2013).

Another interesting discussion raised by the lecturer was about the influence of the heat sink conditions and the impact of exchanging heat with airflow or a heat transfer liquid fluid. In this part, the lecturer had to remind the students of the influence of the heat transfer coefficient (studied in the Heat Transfer course) in heat exchangers.

The lecturer explained that the different conditions simulated aimed to prove the high adaptability of the HTHP to different situations. Moreover, the professor had to explain in detail the effect of subcooling and superheating in the energetic results, using thermodynamic concepts. 
Finally, the lecturer discussed that the economic viability of the HTHP compared to boilers could vary significantly depending on the fossil fuel prices and the electricity tariff (or the availability of self-consumption through renewable energy technologies). Moreover, the professor explained that efficiencies are likely to improve in the coming years with further development of this technology. Some students were interested in the possibilities that offer this technology for using it in Degree thesis.

It must be mentioned that all students delivered the report in time and reflecting most of the topics covered in the course. The final exam included a question related to heat pumps which was (at least) acceptably answered by most of the students.

\section{Conclusions}

Waste heat recovery solutions are going to be needed to decarbornize the industry. The most adequate carbon footprint and economic options are going to be imposed in different processes, and HTHPs represents a possibility for the medium term. An HTHP simulator (HeatPack) has been developed using EES free student version. Hence, this work presents the characteristics of the program designed to be used by students of different Engineering Bachelor's and Master's Degrees. The tool allows the analysis of the operation of HTHPs at different working conditions and working fluids, and the graphical interface has been designed to facilitate this task. This tool allows a quick analysis of the data and the evaluation of the energy, economic and carbon footprint performance of the system to be compared with conventional boilers. A sensibility of the input parameters (working fluid, subcooling and superheating degrees, waste heat rate, heat sink and source temperatures, and working hours) is proposed to the students for a better comprehension of the HTHP operation and their benefits on different aspects. Additionally, the tool is ready to be updated in the short term with new refrigerants, correlations, configurations, or technological concepts. Finally, the utilization of the program can be extended to design engineers to study the feasibility of this technology in different industrial processes.

\section{Declaration of Conflicting Interests}

The authors declared no potential conflicts of interest concerning the research, authorship, and publication of this article.

\section{Funding}

The authors received no financial support for the research, authorship, and/or publication of this article.

\section{References}

Ambusaidi, A., Boyes, E., Stanisstreet, M., \& Taylor, N. (2012). Omani students views about global warming: Beliefs about actions and willingness to act. International Research in Geographical and Environmental Education, 21(1), 21-39. https://doi.org/10.1080/10382046.2012.639154

Antón, R., Jonsson, H., Ramos, J., \& Gómez-Acebo, T. (2009). Refrigerating Cycle Simulator: System Modelling, Educational Implementation and Assessment. International Journal of Engineering Education, 25(2), 324-332.

Arpagaus, C., Bless, F., Schiffmann, J., \& Bertsch, S.S. (2016). Multi-temperature heat pumps: A literature review. International Journal of Refrigeration, 69(2012), 437-465. https://doi.org/10.1016/j.ijrefrig.2016.05.014

Arpagaus, C., Bless, F., Uhlmann, M., Büchel, E., Frei, S., Schiffmann, J. et al. (2018). High temperature heat pump using HFO and HCFO refrigerants - System design, simulation, and first experimental results. 17th International Refrigeration and Air Conditioning Conference at Purdue (1-10).

Balakrishnan, B., \& Woods, P.C. (2013). A comparative study on real lab and simulation lab in communication engineering from students' perspectives. European Journal of Engineering Education. https://doi.org/10.1080/03043797.2012.755499 
Bamigbetan, O., Eikevik, T.M., Nekså, P., Bantle, M., \& Schlemminger, C. (2019). The development of a hydrocarbon high temperature heat pump for waste heat recovery. Energy, 173, 1141-1153.

https://doi.org/10.1016/J.ENERGY.2019.02.159

Bamigbetan, O., Eikevik, T.M., Nekså, P., \& Bantle, M. (2017). Review of vapour compression heat pumps for high temperature heating using natural working fluids. International Journal of Refrigeration, 80, 197-211. https://doi.org/10.1016/j.ijrefrig.2017.04.021

Belman-Flores, J.M., Barroso-Maldonado, J.M., Mendez-Díaz, S., \& Martínez-Martínez, S. (2015). Virtual test bench as a complement to study thermal area: Application in vapor compression systems. Revista Facultad de Ingenieria. https://doi.org/10.17533/udea.redin.n77a08

Cabello, R., Llopis, R., Sánchez, D., \& Torrella, E. (2011). REFLAB: An interactive tool for supporting practical learning in the educational field of refrigeration. International Journal of Engineering Education, 27(4), 909-918.

Cawsey, D.C. (1996). Influencing the Future Through Innovations in Environmental Engineering Education. European Journal of Engineering Education, 21(4), 393-402. https://doi.org/10.1080/03043799608923425

Chaturvedi, S.K., \& Akan, O. (2006). Simulation and Visualization Enhanced Engineering Education. 2006 International Mechanical Engineering Education Conference.

https://www.asme.org/education/college/2006_proceedings.cfm

Dickes, R., Dumont, O., Legros, A., Quoilin, S., \& Lemort, V. (2015). Analysis and comparison of different modeling approaches for the simulation of a micro-scale organic Rankine cycle power plant. Proceedings of ASME-ORC, 180, 1-10. https://doi.org/10.1016/j.rser.2013.01.028

European University Association (2017). Energy Transition and the Future of Energy Research, Innovation and Education: An Action Agenda for European Universities (December). https://energy.eua.eu/downloads/publications/energy-transition.pdf

Frate, G.F., Ferrari, L., \& Desideri, U. (2019). Analysis of suitability ranges of high temperature heat pump working fluids. Applied Thermal Engineering, 150, 628-640. https://doi.org/10.1016/J.APPLTHERMALENG.2019.01.034

Gaggioli, R.A. (2010). Teaching elementary thermodynamics and energy conversion: Opinions. Energy. https://doi.org/10.1016/j.energy.2009.06.022

Granryd, E., Ekroth, I., Lundqvist, P., Melinder, A., Palm, B., \& Rohlin, P. (1999). Refrigeration Engineering. Kungliska Tekniska Högskolan.

Hannay, J.E., MacLeod, C., Singer, J., Langtangen, H.P., Pfahl, D., \& Wilson, G. (2009). How do scientists develop and use scientific software? Proceedings of the 2009 ICSE Workshop on Software Engineering for Computational Science and Engineering, SECSE 2009. https://doi.org/10.1109/SECSE.2009.5069155

Heaton, D., \& Carver, J.C. (2015). Claims about the use of software engineering practices in science: A systematic literature review. Information and Software Technology. https://doi.org/10.1016/j.infsof.2015.07.011

Kaikai, M., \& Baker, E. (2016). Engineering for Sustainable Energy Education within Suburban, Urban and Developing Secondary Schools. Journal of Education for Sustainable Development.

https://doi.org/10.1177/0973408215625536

Klein, S. (2006). Engineering Equation Solver (EES) V10.2. Madison, USA: Fchart Software.

Lemmon, E.W., Bell, I.H., Huber, M.L., \& McLinden, M.O. (2018). NIST Standard Reference Database: Reference Fluid Thermodynamic and Transport Properties-REFPROP, Version 10. Boulder, CO: National Institute of Standards and Technology, Standard Reference Data Program. 
Mahmoudi, A., Fazli, M., \& Morad, M.R. (2018). A recent review of waste heat recovery by Organic Rankine Cycle. Applied Thermal Engineering, 143, 660-675. https://doi.org/10.1016/J.APPLTHERMALENG.2018.07.136

Martin, C.R., Moore, J.P., \& Ranalli, J.A. (2016). Teaching the foundations of thermodynamics with PYro. Proceedings - Frontiers in Education Conference (FIE). https://doi.org/10.1109/FIE.2016.7757589

Mateu-Royo, C., Navarro-Esbrí, J., Mota-Babiloni, A., Amat-Albuixech, M., \& Molés, F. (2018). Theoretical evaluation of different high-temperature heat pump configurations for low-grade waste heat recovery. International Journal of Refrigeration, 90, 229-237. https://doi.org/10.1016/j.ijrefrig.2018.04.017

Mateu-Royo, C., Navarro-Esbrí, J., Mota-Babiloni, A., Molés, F., \& Amat-Albuixech, M. (2019). Experimental exergy and energy analysis of a novel high-temperature heat pump with scroll compressor for waste heat recovery. Applied Energy, 253, Article 113504. https://doi.org/10.1016/j.apenergy.2019.113504

Michna, G.J., \& Gent, S. (2011). Assessing and Updating an Undergraduate Thermo-Fluids Laboratory Course. 2011 ASEE annual conference \& exposition. https:// doi.org/10.18260/1-2--17512

Mota-Babiloni, A., Mateu-Royo, C., Navarro-Esbrí, J., Molés, F., Amat-Albuixech, M., \& Barragán-Cervera, Á. (2018). Optimisation of high-temperature heat pump cascades with internal heat exchangers using refrigerants with low global warming potential. Energy, 165, 1248-1258.

https://doi.org/10.1016/j.energy.2018.09.188

Navarro-Peris, E., Corberán, J.M., Falco, L., \& Martínez-Galván, I.O. (2013). New non-dimensional performance parameters for the characterization of refrigeration compressors. International Journal of Refrigeration, 36(7), 1951-1964. https://doi.org/10.1016/J.IJREFRIG.2013.07.007

Nitkiewicz, A., \& Sekret, R. (2014). Comparison of LCA results of low temperature heat plant using electric heat pump, absorption heat pump and gas-fired boiler. Energy Conversion and Management. https://doi.org/10.1016/j.enconman.2014.07.032

Peris-Pérez, B., Navarro-Esbrí, J., Molés, F., Mota-Babiloni, A., Amat-Albuixech, M., Mateu-Royo, C. et al. (2018). Low GWP working fluids for reversible systems of High Temperature Heat Pump and Organic Rankine Cycle (HTHP/ORC). 13th IIR Gustav Lorentzen Conference. https://doi.org/10.18462/iir.gl.2018.1210

Rogelj, J., Den Elzen, M., Höhne, N., Fransen, T., Fekete, H., Winkler, H. et al. (2016). Paris Agreement climate proposals need a boost to keep warming well below $2{ }^{\circ} \mathrm{C}$. Nature.

https://doi.org/10.1038/nature18307

Taraban, R., Anderson, E.E., DeFinis, A., Brown, A.G., Weigold, A., \& Sharma, M.P. (2007). First steps in understanding engineering students growth of conceptual and procedural knowledge in an interactive learning context. Journal of Engineering Education. https://doi.org/10.1002/j.2168-9830.2007.tb00915.x

Tebbe, P.A., Weisbrook, C., Lombardo, S.J., \& Miller, W. (2001). Development of Software Applications for Thermodynamics Related Courses: The Thermoview Project. In American Society for Engineering Education (Ed.), 2001 American Society for Engineering Education Annual Conference \& Exposition Copyright (6.380.1-6.380.6). https://peer.asee.org/9133

Ugursal, V.I., \& Cruickshank, C.A. (2015). Student opinions and perceptions of undergraduate thermodynamics courses in engineering. European Journal of Engineering Education, 40(6), 593-610. https://doi.org/10.1080/03043797.2014.987646

Universitat Jaume I (2019). UJI's website (english version). https://www.uji.es/?urlRedirect=https://www.uji.es/\&url=/

Wallerand, A.S., Kermani, M., Kantor, I., \& Maréchal, F. (2018). Optimal heat pump integration in industrial processes. Applied Energy, 219, 68-92. https://doi.org/10.1016/j.apenergy.2018.02.114 
Wright, K. (2018). Collaborative Projects with simulation assignments in mechanical engineering thermodynamics courses. International Journal of Mechanical Engineering Education.

https://doi.org/10.1177/0306419018803624

Zueco, J. (2013). An educational laboratory virtual EES for encouraging the use of computer programming in thermal engineering problems. Computer Applications in Engineering Education. https://doi.org/10.1002/cae.20514

Zühlsdorf, B., Jensen, J.K., \& Elmegaard, B. (2019). Heat pump working fluid selection-economic and thermodynamic comparison of criteria and boundary conditions. International Journal of Refrigeration, 98, 500-513. https://doi.org/10.1016/J.IJREFRIG.2018.11.034

Published by OmniaScience (www.omniascience.com)

Journal of Technology and Science Education, 2021 (www.jotse.org)

\section{(ㄷ) (1) $\circledast$}

Article's contents are provided on an Attribution-Non Commercial 4.0 Creative commons International License. Readers are allowed to copy, distribute and communicate article's contents, provided the author's and JOTSE journal's names are included. It must not be used for commercial purposes. To see the complete licence contents, please visit https://creativecommons.org/licenses/by-nc/4.0/. 